Jurnal Ilmu dan Teknologi Kesehatan

Vol 8, No 1, September 2020,

ISSN: 2338-9095 (Print)

ISSN: 2338-9109 (online)

\title{
Snow Balling and Brainstorming Method In Pregnant Mother Classes
}

\author{
Mardeyanti, Siti Masitoh \\ Poltekkes Kemenkes Jakarta III, Indonesia \\ Email:marde_yanti@yahoo.com
}

\author{
Article history \\ Posted, Sept 18th, 2020 \\ Reviewed, Feb 13th, 2021 \\ Received, March 15th, 2021
}

\section{ABSTRACT}

During pregnancy, there are system changes that require adaptation, both physiological and psychological. With these changes, pregnant women must know and understand what they are experiencing, so they need health education during pregnancy and how to prepare for safe delivery. Mother class is a means of learning together about pregnant women's health, increasing knowledge, change attitudes and mothers' behavior. The purpose of this study was to determine the differences in health education with snowballing and brainstorming methods in pregnant women in the class to increase knowledge and attitudes about preparation for pregnancy and childbirth. This study's design was Quasi-experimental with a pretest-posttest design of two snowballing groups and a brainstorming group. The number of samples for each group of 30 pregnant women. Analysis with Chi-Square and T-Test. The study results showed significant differences in knowledge and attitudes on the snowballing method ( $p$ value of 0.000) and the brainstorming method with a p-value of knowledge of 0.011 and attitude of 0.000. Health education using snowballing has a more substantial effect, especially on the attitudes of pregnant women.

Keywords: brainstorming; class of pregnant; snow balling

\begin{abstract}
ABSTRAK
Kehamilan merupakan proses fisiologis. Selama kehamilan terjadi perubahan sistem dalam tubuh yang membutuhkan adaptasi, baik fisiologis maupun psikologis. Dengan perubahan tersebut ibu hamil harus mengetahui dan memahami apa yang dialami, sehingga perlu penyuluhan kesehatan selama hamil dan bagaimana mempersiapkan persalinan yang aman. Kelas Ibu merupakan sarana untuk belajar bersama tentang kesehatan ibu hamil, yang bertujuan untuk menambah pengetahuan, merubah sikap dan perilaku ibu. Tujuan dari penelitian ini untuk mengetahui pengaruh penyuluhan kesehatan dengan metode snow balling dan brain storming di kelas ibu hamil terhadap peningkatan pengetahuan dan sikap tentang persiapan kehamilan dan persalinan. Desain penelitian ini adalah Quasi-eksperimen dengan rancangan Pretest-posttest pada dua kelompok Snow Balling dan kelompok Brain Storming. Jumlah sampel tiap kelompok $30 \mathrm{ibu}$ hamil. Analisis dengan Chi Square dan T-Test. Hasil penelitian menunjukan ada perbedaan yang signifikan pengetahuan dan sikap pada metode snow balling dengan $\mathrm{p}$-value 0,000 , dan metode brain storming dengan $\mathrm{p}$-value pengetahuan
\end{abstract}


0,011 dan sikap 0,000. Pendidikan kesehatan yang dilakukan dengan menggunakan snow balling berpengaruh yang lebih kuat terutama terhadap sikap ibu hamil.

Kata Kunci: Brain Storming; Kelas Ibu; Snow Balling

\section{INTRODUCTION}

Maternal Mortality Rate (MMR) and Infant Mortality Rate (IMR) are indicators of health development. Based on 2015 National Survey data MMR 305 and IMR 22.23 (Kemenkes RI 2012, 2012). So until now, the health development program in Indonesia is still prioritized to improve mothers' and children's health status, especially in the groups most vulnerable to health, namely pregnant women, childbirth, and infants during the perinatal period.

Pregnancy is a physiological process experienced by women. In pregnancy, there is a change in the body's system that requires an adaptation, both physical and psychological. With this condition, pregnant women must know and understand what is experienced during pregnancy, so pregnant women need to learn health education (Kurniarum, 2016). Much maternal and child health education is still carried out through individual consultations or on a case-by-case basis, given during antenatal care. This extension activity helps handle case-by-case. However, it has weaknesses: the knowledge obtained is limited to the health problems experienced during the consultation. The counseling provided is not coordinated so that the knowledge given to mothers is only the knowledge that the mother owns. The officers themselves do not have a work plan, so that there is no monitoring and coaching across sectors and programs, the implementation of counseling is unscheduled and unsustainable (Kementerian Kesehatan Republik Indonesia, 2014).

The Ministry of Health has developed a class method for pregnant women. The planned activity discusses the $\mathrm{MCH}$ book material face-to-face in groups, followed by discussions and sharing experiences between pregnant women and health workers. This class for pregnant women is a means of learning together about health for pregnant women, in the form of faceto-face meetings in groups that aim to increase knowledge, change mothers' attitudes and behavior to understand pregnancy, body changes, and complaints. During pregnancy, pregnancy care, childbirth, postpartum care, postpartum 
birth control, newborn care, local myths/beliefs/customs, infectious diseases, and birth certificates (Kementerian Kesehatan Republik Indonesia, 2014). Through classes for prospective mothers, there is interaction and sharing of experiences between participants and midwives or health workers about pregnancy, body changes, and complaints during pregnancy, pregnancy care, childbirth, delivery care, baby care, myths, infectious diseases, and birth certificates. Through classes, it is hoped that pregnant women can carry out early detection of risk factors during pregnancy to reduce maternal mortality and morbidity (Kementerian Kesehatan Republik Indonesia, 2014). The position of the Pregnant Woman Class is shown in Quadrant III (negative, positive). This position indicates a weak but very likely organization. The strategy recommendation given is Change Strategy (Fuada and Setyawati, 2016)

Pregnant women have a good knowledge of $43.8 \%$ and participate in the class of $68.8 \%$ pregnant women. There is a significant relationship between the knowledge variable and pregnant women's class participation ( $\rho=0.000$, rs 0.554). The pregnant mothers class is a collaborative learning tool that pregnant

women need to follow to gain sufficient knowledge to prevent complications and increase K4 coverage (Baroroh, Jannah, and Meikawati, 2017). The results showed that more than half $(70.2 \%)$ of pregnant women were not actively participating in the class of pregnant women and less than half $(47.4 \%)$ of pregnant women had less knowledge about the danger signs of pregnancy. There is a relationship between pregnant women's class and mothers' knowledge about the danger signs of pregnancy in Surawangi Village (Nuryawati and Budiasih, 2017).

The national strategy and national policy direction for 2015-2019 have a target for 2019 by increasing access to and quality of infant, child, and adolescent health services. One of these targets is the percentage of community health centers implementing pregnant women classes by 90\% (Kementrian Kesehatan Republik Indonesia, 2017). The results showed that the percentage of postpartum mothers with common knowledge was $54.5 \%$, postpartum mothers with good attitude was $68.2 \%$. Postpartum mothers with excellent practice were $57.6 \%$. There were associations between the maternity class attendance and knowledge $(\mathrm{p}=0.002)$ and attitude ( $\mathrm{p}=0.013)$ (Khofidzoh, Rahfiludin, and Kartasurya, 2016).

\section{DOI: $10.32668 /$ jitek.v812.442}


Health education using simulation games and brainstorming methods can increase adolescent knowledge about breast cancer in XII grade students of SMAN 4 Malang. The simulation game method is more effective than brainstorming in increasing adolescent knowledge about breast cancer (Maharani, Wati, and Sariati, 2019). Health Education Methods, brainstorming, and buzz groups influence respondents' knowledge about the danger signs of pregnancy, childbirth, and childbirth (Winancy et al., 2015). There are significant differences before and after being given health education with the brainstorming method and videos in the treatment group (Syafi'udin, Wantiyah, and Kushariyadi, 2018).

This research aims to determine the effect of health education on snowballing and brainstorming methods in pregnant women's classes to increase knowledge and attitudes about pregnancy and childbirth preparation at the Puskesmas Kelurahan Pondok Ranggon I.

\section{METHOD}

This research is a quantitative study with a quasi-experimental design with a pretestposttest design in two groups. In this design, sample members in the experimental and control groups are not done randomly or randomly. This research sees the intervention's effect, namely health education with the snowballing method in pregnant women. This study involved a class group of pregnant women with the brainstorming method to compare the intervention results. The research was conducted in the Pondok Rangon I Village Community Health Center from June to September 2018.

The study population was pregnant women in the third trimester who participated in the class of pregnant women in the Pondok Rangon I village health center's working area. The sample selection technique used accidental sampling. Every pregnant woman with a gestational age of 16-36 weeks who met and met the criteria as a sample would be the research respondents. The number of samples for each group was 30 pregnant women. The instrument used for data collection was a class questionnaire for pregnant women pre and post, based on questions on pregnant women's class. The intervention provided health education in pregnant women's classes to groups using the snowballing method and groups using the brainstorming method.

To determine the difference in the mean value of pregnant women's knowledge and 
attitudes after being given health education between the snowballing method group and the brainstorming method group using the Paired-test. To determine pregnant women's characteristics on knowledge and attitudes about pregnancy and preparation for delivery with the Manova test.

This research has received ethical approval by the number KEPK-PKKJ3/173/IV/2018

\section{RESULTS AND DISCUSSION}

This study describes the relationship between the respondents' characteristics (age, education, and parity) with the knowledge and attitudes of pregnant women about pregnancy and preparation for delivery. This study compared the results of measuring respondents' knowledge and attitudes after receiving health education between the snowballing and brainstorming groups.

Table 1. Relationship of age, education, and parity with pregnant women's knowledge about pregnancy and childbirth preparation

\begin{tabular}{|c|c|c|c|c|c|c|c|c|}
\hline Characteristics & Good & $\%$ & Less & $\%$ & amount & $\%$ & $\begin{array}{c}\text { Chi- } \\
\text { Square }\end{array}$ & p-value \\
\hline \multicolumn{9}{|l|}{ Knowledge } \\
\hline \multicolumn{9}{|l|}{ Age } \\
\hline$-\geq 35$ years old & 20 & 74.1 & 7 & 25.9 & 27 & 100 & 2,134 & 0.144 \\
\hline$-<35$ years old & 1 & 33.3 & 2 & 66.7 & 3 & 100 & & \\
\hline \multicolumn{9}{|l|}{ Education } \\
\hline - tall & 17 & 73.9 & 6 & 26.1 & 23 & 100 & 0719 & 0.397 \\
\hline - low & 4 & 57.1 & 3 & 42.9 & 7 & 100 & & \\
\hline \multicolumn{9}{|l|}{ Parity } \\
\hline - Primipara & 10 & 58.8 & 7 & 41.2 & 17 & 100 & 2,334 & 0.127 \\
\hline - Multipara & 11 & 84.6 & 2 & 15.4 & 13 & 100 & & \\
\hline \multicolumn{9}{|l|}{ Attitude } \\
\hline \multicolumn{9}{|l|}{ Age } \\
\hline - $\geq 35$ years old & 21 & 77.8 & 6 & 22.2 & 27 & 100 & 0833 & 0.361 \\
\hline - $<35$ years old & 3 & 100 & 0 & 0 & 3 & 100 & & \\
\hline \multicolumn{9}{|l|}{ Education } \\
\hline High & 17 & 73.9 & 6 & 26.1 & 23 & 100 & 2,283 & 0.131 \\
\hline - Low & 7 & 100 & 0 & 0 & 7 & 100 & & \\
\hline \multicolumn{9}{|l|}{ Parity } \\
\hline - Primipara & 14 & 82.4 & 3 & 17.6 & 17 & 100 & 0.136 & 0713 \\
\hline - Multipara & 10 & 76.9 & 3 & 23.1 & 13 & 100 & & \\
\hline
\end{tabular}

The relationship between respondents' characteristics and knowledge shows that the variable age with chi-square is 2.134 and a p-value of 0.144 . It can be concluded 
that there is no relationship between education and the respondent's knowledge. The education variable with a chi-square of 0.719 and a p-value of 0.397 indicates no relationship between education and the respondent's knowledge. Parity with chisquare 2.334 and p-value 0.127 can be concluded that there is no relationship between parity and respondent's knowledge.

The relationship between the respondents' characteristics and attitudes indicates that the age variable is obtained chi-square 0.833 with a p-value of 0.361 . It can be concluded that there is no relationship between age and the respondents' attitude. The education variable is obtained chisquare 2,283 with a p-value 0.131 . It can be concluded that there is no relationship between education and the respondents' attitude. The parity variable is obtained chi-square 0.136 with a p-value of 0.713 , so it can be concluded that there is no relationship between parity and respondent's attitude.
This research is supported by Silfia's research which states there is no relationship between age, economic status, and parity with IVA examination. However, the education variable a significant relationship between education, knowledge, and attitudes with the IVA examination (Nita Silfia and Muliati, 2017). According to Rahmadani, respondents with age are not at risk of having a trend 15.4 times more prepared to face labor than respondents who have aged at risk. Respondents with primiparous parity tend to be 5.19 times more ready for labor than those with multiparity parity.

Moreover, most respondents who have labor readiness with the ready category are respondents with secondary education level, namely as many as 13 respondents (65\%) (Rahmadani, 2017). Cooperative learning with the snowball throwing model effectively increase knowledge in the first and second cycle, can affect the attitude of the second cycle and the personal hygiene practices in the first cycle (Fitriayunda, 2017). 
Table 2. Relationship of age, education, and parity with the knowledge of pregnant women about pregnancy and childbirth preparation in the Brain Storming Group

\begin{tabular}{|c|c|c|c|c|c|c|c|c|}
\hline Characteristics & Good & $\%$ & Less & $\%$ & Amount & $\%$ & $\begin{array}{c}\text { Chi } \\
\text { Square }\end{array}$ & p-value \\
\hline \multicolumn{9}{|l|}{ Knowledge } \\
\hline $\begin{array}{l}\text { Age : } \\
\leq 35 \text { years old }\end{array}$ & 10 & 35.7 & 18 & 64.3 & 28 & 100 & 0.685 & 0.164 \\
\hline$>35$ years old & 1 & 50.0 & 1 & 50.0 & 2 & 100 & & \\
\hline $\begin{array}{l}\text { Education: } \\
\text { High } \\
\text { Low }\end{array}$ & $\begin{array}{l}10 \\
1 \\
\end{array}$ & $\begin{array}{l}47.6 \\
11.1 \\
\end{array}$ & $\begin{array}{l}11 \\
8 \\
\end{array}$ & $\begin{array}{l}52.4 \\
88.9 \\
\end{array}$ & $\begin{array}{l}21 \\
9 \\
\end{array}$ & $\begin{array}{l}100 \\
100 \\
\end{array}$ & 3,616 & 0.057 \\
\hline $\begin{array}{l}\text { Parity: } \\
\text { Primipara } \\
\text { Multipara }\end{array}$ & $\begin{array}{l}1 \\
10\end{array}$ & $\begin{array}{l}20.0 \\
40.0\end{array}$ & $\begin{array}{l}4 \\
15\end{array}$ & $\begin{array}{l}80.0 \\
60.0\end{array}$ & $\begin{array}{l}5 \\
25\end{array}$ & $\begin{array}{l}100 \\
100\end{array}$ & 0.397 & 0.718 \\
\hline Attitude & & & & & & & & \\
\hline $\begin{array}{l}\text { Age : } \\
\leq 35 \text { years old } \\
>35 \text { years old }\end{array}$ & $\begin{array}{l}14 \\
2\end{array}$ & $\begin{array}{l}50.0 \\
100\end{array}$ & $\begin{array}{l}14 \\
0\end{array}$ & $\begin{array}{l}50.0 \\
0.0\end{array}$ & $\begin{array}{l}28 \\
2 \\
\end{array}$ & $\begin{array}{l}100 \\
100\end{array}$ & 1,875 & 0.171 \\
\hline $\begin{array}{l}\text { Education: } \\
\text { High } \\
\text { Low }\end{array}$ & $\begin{array}{l}12 \\
4\end{array}$ & $\begin{array}{l}57.1 \\
44.4\end{array}$ & $\begin{array}{l}9 \\
5\end{array}$ & $\begin{array}{l}42.9 \\
55.6\end{array}$ & $\begin{array}{l}21 \\
9\end{array}$ & $\begin{array}{l}100 \\
100\end{array}$ & 0.523 & 0.408 \\
\hline $\begin{array}{l}\text { Parity: } \\
\text { Primipara } \\
\text { Multipara }\end{array}$ & $\begin{array}{l}2 \\
14\end{array}$ & $\begin{array}{l}40.0 \\
56.0\end{array}$ & $\begin{array}{l}3 \\
11\end{array}$ & $\begin{array}{l}60.0 \\
44.0\end{array}$ & $\begin{array}{l}5 \\
25\end{array}$ & $\begin{array}{l}100 \\
100\end{array}$ & 0.513 & 0.429 \\
\hline
\end{tabular}

The table above illustrates the relationship of respondent characteristics to knowledge in the brainstorming group. These results indicate that the age variable is obtained chi-square 0.685 with a p-value 0.164 , so it can be concluded that there is no relationship between age and respondent's knowledge. The educational variable is obtained chi-square 3.616 with a p-value of 0.057 , so it can be concluded that there is no relationship between education and respondent's knowledge. The parity variable is obtained chi-square 0.397 with a p-value of 0.718 , it can be concluded that there is no relationship between parity and respondent's knowledge.

This table also shows the relationship of respondent characteristics to attitudes. These results indicate that the age variable obtained chi-square 1,875 with a $p$-value 0.171 , it can be concluded that there is no relationship between age and the attitude of respondents. The education variable is obtained chi-square 0.523 with a $\mathrm{p}$-value of 0.408 , so it can be concluded that there is no relationship between education and the respondents' attitude. Parity variable is 
obtained by chi-square 0.513 with p-value 0. 429 , so it can be concluded that there is no relationship between parity and respondent's attitude.

The results of the analysis of education, age, and parity show a p-value> 0.05, meaning that education, age, and parity do not have a significant relationship to pregnant women's knowledge and attitudes. Knowledge and attitudes of pregnant women are not only influenced by age, education, and parity. Factors that influence pregnant women's health behavior in performing ANC are divided into predisposing factors, supporting factors, and reinforcing factors. Predisposing factors consist of age, level of education, occupation, parity, knowledge, and attitudes of pregnant women. Supporting factors include residence distance, family income, and existing media information facilities. Meanwhile, reinforcing factors include husband's support, family support, and attitudes and support from health workers (Rachmawati, Puspitasari, and Cania, 2017).

This result is also different from the theory that the higher the level of education, it will be easy to accept new things and adjust to these new things (Notoatmodjo,
2016). Someone with a higher education level readily accepts the information received, has more knowledge, and has broader insight than people with low education. However, someone who has less education does not have standard knowledge. An experience is a condition that someone experienced by repeating the knowledge obtained from oneself or others in the past. In this case, it is the parity of the mother. A less good experience tends to be forgotten by someone, but if the experience can make a psychological sense of pleasure, there will be an impression left behind to produce a positive attitude (Budiman; Riyanto, 2013). With higher education, the experience will be broader. This is done by repeating the knowledge gained in solving problems encountered in the past (Notoatmodjo, 2016)

Health education with brainstorming and lecture (Brace) method about menstruation at SMP Islam Manbaul Ulum Gresik improves female students' knowledge and attitude with a knowledge p-value of 0,000 and attitude 0.001 (Naganingrum, 2014). Health education (lectures, brainstorming, and discussion) affects pregnant women's knowledge about pregnancy complications at Puskesmas Karangdoro(Sari and Sudarmiati, 2017). 
Table 3. Differences in Knowledge and Attitudes of Pregnant Women about Pregnancy and Childbirth Preparation Before and After Health Education in the Snow Balling and Brain Storming Group

\begin{tabular}{lcccc}
\hline $\begin{array}{l}\text { Dependent } \\
\text { Variable }\end{array}$ & The mean & SD & SE & P-value \\
\hline Snow Balling Group & & & & \\
\hline Knowledge & 9.40 & 1905 & 348 & 0,000 \\
Before & 11.83 & 1,206 & 220 & \\
After & & & & \\
\hline Attitude & 26.27 & 1,450 & 0.383 & \\
Before & 29.03 & & 0.265 & \\
After & & & & \\
\hline Brain Storming Group & & 1,714 & .313 & \\
\hline Knowledge & 8.40 & 1,406 & 257 & 0,000 \\
Before & 9.23 & & & \\
After & & 1993 & .364 & \\
\hline Attitude & 1,343 & .245 & \\
Before & 26.40 & & & \\
After & 27.30 & & & \\
\hline
\end{tabular}

Before and after health education, respondents' level of knowledge using the snowballing method obtained the mean results before doing 9.40 and after increasing to 11.83 with a p-value of 0.000. These results indicate a significant difference in respondents' knowledge after using the snowballing method. The mean results of knowledge on the brainstorming method were obtained before 8.40 and after increasing 9.23 with a p-value of 0.011. These results indicate a significant difference in the respondents' knowledge after health education using the brainstorming method. Attitudes before and after health education with the snowballing method obtained results with a p-value of 0.000 . These results indicate significant differences in respondent knowledge after health education using the snowballing method. Before and after health education, the respondents' attitude with the brainstorming method obtained results with a p-value of 0,000 . This result also shows significant differences in the attitudes of respondents after health education using the brainstorming method.

The Snowball method for increasing knowledge and attitudes is more effective than the lecture method. It can be seen from the increase in the intervention 
group's knowledge level, reaching 63\%. In comparison, the control group reached 37\%.(Megatsari and Deliana, 2014). Increasing knowledge in line with the results or values obtained, the snowball throwing learning model in this study can improve post-test scores (Fitriayunda, 2017). There is a significant relationship between maternal participation in pregnant women's classes and pregnant women's knowledge and attitudes (Kaspirayanthi, Suarniti, and Somoyani, 2019). The Snowball method can improve the community's knowledge and attitudes in RW 06 Tomang Village about DHF (Megatsari and Deliana, 2014). Attitude is a specific order in terms of feelings (affection), thoughts (cognition), and predisposition to actions of a person towards an aspect in the surrounding environment". It can be concluded that after getting health education, pregnant women have feelings, thoughts, and predisposition to actions (behavior) about something new that they know, in this case, is the result of health education (Azwar, 2013).
This study's results indicate that the respondent's attitude with the brainstorming method obtained a p-value of 0,000 . An experience is an event or situation that someone has experienced by repeating knowledge obtained from oneself or others in the past. A bad experience tends to be forgotten by someone, but if the experience can make a psychological sense of pleasure, then the impression that will be left behind will result in a positive attitude (Budiman; Riyanto, 2013). The study results are supported by research about the effect of implementing the class of pregnant women on knowledge with a p-value of 0.000 , namely the presence of meaningful differences in knowledge (Lucia, Purwandari, and Pesak, 2015). The snowballing method is a method that emphasizes the active role of participants in groups to achieve common goalslearning the snowball method on increasing people's knowledge and attitudes about DHF where the results show that the effective snowball method increases people's knowledge and attitudes about DHF (Ariefani Deliana and Megatsari, 2014). 
Table 4. Influence of Health Education on Increasing Knowledge and Attitudes of Pregnant

Women about Pregnancy and Childbirth Preparation

\begin{tabular}{lccc}
\hline \multicolumn{1}{c}{$\begin{array}{c}\text { Dependent } \\
\text { Variable }\end{array}$} & P-value & $\boldsymbol{\alpha}$ & 95\% CI \\
\hline Knowledge & & & \\
Before & 0.037 & 0.05 & $0.064-1,936$ \\
After & 0,000 & 0.05 & $1,923-3,277$ \\
\hline Attitude & & & \\
Before & 0.802 & 0.05 & $-1.191-0.925$ \\
After & 0,000 & 0.05 & $1,011-2,456$ \\
\hline
\end{tabular}

In the knowledge variable obtained pvalue 0.000 , this result shows that the snowballing method in pregnant women's class causes an increase in knowledge that is very good compared with the brainstorming method. The attitude variable with a p-value of 0.000 after health education means an increase in attitude towards a positive direction occurs in the snowballing group.

On differences in knowledge and attitudes before and after learning snowball throwing about the maturity of marriage age in class IV and VIII students of AnNur Sungai Asam Village (p-value 0.000. These results conclude that the snowball throwing learning method can improve the knowledge and attitude of grade IV and VIII students of MTS A-Nur Sungai Desa (Umairoh, Suwarni, and Mardjan, 2019).

Model and approaches to health promotion in the midwifery world, one of which is the education approach. Health education is defined as all the effects that combine to influence knowledge, beliefs, and behavior related to the promotion, management, and improvement of health in individuals and society. The educational process with twoway communication; in this process, learning and teaching activities can come from midwives and women, or both (Adventus, Jaya and Mahendra, 2016). The Snow Balling method, when compared to Brain Storming, participants will be more active and have more twoway communication on the Snow Balling method. Following the class goals of pregnant women, namely the occurrence of interaction and sharing of experiences between participants (pregnant women with pregnant women) and between pregnant women with health workers/midwives about pregnancy, body changes and complaints during pregnancy, pregnancy care, childbirth, Postpartum Care, Postpartum contraception, newborn 
care, local myths/beliefs/customs, understanding, attitudes, and behavior of infectious diseases, and birth certificates. pregnant women.

Another goal is to increase the

Table 5. Influence of Education, Age, and Parity on Knowledge and Attitudes of Pregnant Mothers about Pregnancy and Childbirth Preparation After Health Education

\begin{tabular}{llccc}
\hline $\begin{array}{l}\text { Independent } \\
\text { Variable }\end{array}$ & $\begin{array}{l}\text { Dependent } \\
\text { Variable }\end{array}$ & Mean Square & F & Sig. \\
\hline Education & Knowledge & 12,685 & 2,676 & 0.107 \\
\cline { 2 - 5 } & Attitude & 0.055 & 0.011 & 0.916 \\
\hline Age & Knowledge & 1,964 & 0.999 & 0.530 \\
\cline { 2 - 5 } & Attitude & 4,418 & 0.928 & 0.339 \\
\hline Parity & Knowledge & 22,232 & 4,859 & 0.031 \\
\cline { 2 - 5 } & Attitude & 36,657 & 8,166 & 0.005 \\
\hline
\end{tabular}

Education shows results, knowledge 0107 and attitude 0.916, which can be concluded that education does not affect pregnant women's knowledge and attitudes after getting health education. Age variable with sig. 0.530 for knowledge and 0.339 for attitude. These results also showed no significant effect on pregnant women's education on knowledge and attitudes after getting health education. Parity variable results obtained for maternal knowledge $0.031<0.05$, it can be concluded that parity affects mothers' knowledge after getting health education. So, the attitude with sig. $0.005<0.05$, it is concluded that parity affects the attitude of the mother. The results of the analysis of education and age together show a pvalue> 0.05 , meaning that education and age do not have a meaningful relationship to knowledge and attitudes. But parity with 0.031 knowledge results and attitudes with sig. $0.005<0.05$, it is concluded that parity affects knowledge and attitudes.

Attitude can be obtained from experience. According to Budiman (2013), experience is an event or situation that someone has experienced by repeating knowledge obtained from oneself or others in the past. A bad experience tends to be forgotten by someone. However, if the experience can make a psychological sense of excitement, the impression will be left behind to produce a positive attitude. Attitude serves as a tool to measure experiences. In this case, it needs to be stated that the human being in receiving experiences from the outside world is not passive but actively accepted, meaning that the experiences 
originating from the outside world are not all served by humans. However, humans choose which ones are necessary and which ones no need to be served. Education is guidance given to someone from others about a matter in order to increase understanding and be able to understand the material. Someone who has a higher level of education, readily accepts the information received, has more knowledge, and has broader insight compared to people with low education, but someone who has less education does not mean to have low knowledge (Budiman, 2013).

\section{CONCLUSION}

This study compares the results of measuring respondents' knowledge and attitudes after receiving health education between the snowballing and brainstorming groups. It can be concluded that the use of the snowballing method in the class of pregnant women causes a tremendous increase in knowledge when compared to the brainstorming method. Likewise, with attitude, there was an increase in attitude towards a positive direction in the snowballing group.

\section{REFERENCES}

Adventus, Jaya, I. M. M. And Mahendra, D. (2016). Buku Ajar Promosi Kesehatan. Jakarta: Pusdik SDM
Kesehatan.

Azwar, S. (2013). Sikap Manusia: Teori Dan Pengukurannya. Yogyakarta: Pustaka Pelajar

Baroroh, I., Jannah, M. And Meikawati, P.R. (2017). Hubungan Pengetahuan Ibu Hamil Dengan Keikutsertaan Kelas Ibu Hamil Di Wilayah Kerja Puskesmas Jenggot Kota Pekalongan. Siklus: Journal Research Midwifery Politeknik Tegal, 6(2). DOI: 10.30591/Siklus.V6i2.579.

Budiman; Riyanto. (2013). Kapita Selekta Kuesioner: Pengetahuan Dan Sikap Dalam Penelitian Kesehatan, Penerbit Salemba Medika, Jakarta: Salemba Medika

Deliana, L.A. (2014). Pengaruh Pembelajaran Metode Snow Ball Terhadap Peningkatan Pengetahuan Dan Sikap Masyarakat Tentang DBD Wilayah Puskesmas Kecamatan Grogol Petamburan Kota Administrasi Jakarta Barat Provinsi Dki Jakarta. Doctoral Dissertation, Universitas Airlangga).

Fitriayunda, S. (2017). Efektivitas Model Pembelajaran Snowball Throwing Dalam Meningkatkan Higiene Pribadi Santriwati. Jurnal of Health Education. DOI: 10.15294/jhe.v2i1.19115

Fuada, N. And Setyawati, B. (2015). Pelaksanaan Kelas Ibu Hamil Di Indonesia. Indonesian Journal of Reproductive Health, 6(2), 67-75.

Kaspirayanthi, N. K. D., Suarniti, N. W. And Somoyani, N. K. (2019). Hubungan Keikutsertaan Ibu Dalam Kelas Ibu Hamil Dengan Pengetahuan Dan Sikap Terhadap Tanda Bahaya Dalam Kehamilan Di 
Kota Bogor. Jurnal Kesehatan Reproduksi.

Kemenkes RI. (2012). Profil Kesehatan Indonesia 2011. Jakarta : Kemenkes Ri.

\begin{tabular}{|c|c|c|}
\hline $\begin{array}{l}\text { Kementerian } \\
\text { Indonesia. }\end{array}$ & $\begin{array}{r}\text { Kesehatan } \\
\text { (2014) }\end{array}$ & $\begin{array}{l}\text { Republik } \\
\text { Pedoman }\end{array}$ \\
\hline Pelaksanaan & Kelas & Ibu Hamil \\
\hline
\end{tabular}

Kementrian Kesehatan Republik Indonesia. (2017). Inilah Capaian Kinerja Kemenkes RI Tahun 20152017.

Khofidzoh, A., Rahfiludin, M.Z. And Kartasurya, M.I. (2016). Hubungan Keikutsertaan Kelas Ibu Hamil Dengan Perilaku Ibu Dalam Perawatan Masa Nifas (Studi Di Puskesmas Cepiring Kabupaten Kendal). Jurnal Kesehatan Masyarakat (E-Journal), 4(3), 147157.

Kurniarum, A. (2016). Asuhan Kebidanan Persalinan Dan BBL. Jakarta: Pusdik SDM Kesehatan.

Lucia, S., Purwandari, A. And Pesak, E. (2015). Pengaruh Pelaksanaan Kelas Ibu Hamil Terhadap Pengetahuan Tentang Persiapan Persalinan. Jidan (Jurnal Ilmiah Bidan), 3(1), 61-65.

Maharani, S.A., Wati, L.R. And Sariati, Y. (2019). Perbandingan Efektivitas Penyuluhan Kesehatan Antara Metode Brain Storming Dan Simulation Game (Sig) Terhadap Peningkatan Pengetahuan Mengenai Kanker Payudara Pada Siswi Kelas XII Sman 4 Malang. Journal of Issues In Midwifery, 3(1), 33-47. DOI:10.21776/Ub.Joim.2019.003.01 .5 .
Megatsari, H. And Deliana, L. A. (2014). Pengaruh Pembelajaran Metode Snow Ball Terhadap Peningkatan Pengetahuan Dan Sikap Masyarakat Tentang Dbd. Jurnal Promosi Kesehatan Indonesia, 2(1), 49-57

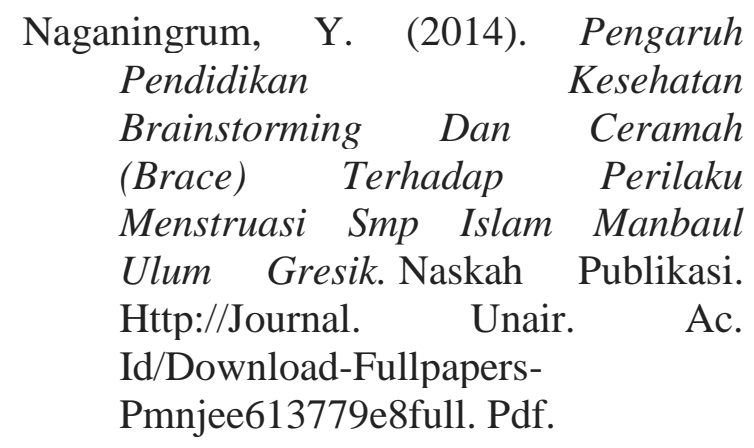

Silfia, N.N. And Muliati, T. (2017). Hubungan Karakteristik, Pengetahuan Dan Sikap Dengan Pemeriksaan Inspeksi Visual Asam Asetat (Iva) Pada Ibu Pasangan Usia Subur Di Puskesmas Talise. Journal Center Of Research Publication In Midwifery And Nursing, 1(2). DOI: 10.36474/Caring.V1i2.8.

Notoatmodjo, S. (2016). Ilmu Prilaku Kesehatan. Jakarta: PT Rineka Cipta..

Nuryawati, S.B.L.S. (2017). Hubungan Kelas Ibu Hamil Dengan Pengetahuan Ibu Hamil Tentang Tanda-Tanda Bahaya Kehamilan Di Desa Surawangi Wilayah Kerja Uptd Puskesmas Jatiwangi Kabupaten Majalengka Tahun 2016. Jurnal Bidan, 3(1), 234036.

Rachmawati, A.I., Puspitasari, R.D. And Cania, E. (2017). Faktor-Faktor Yang Memengaruhi Kunjungan Antenatal Care (Anc) Ibu Hamil. Jurnal Majority, 7(1), 72-76.

Rahmadani, R. And Utami, F.S. (2017). Faktor-Faktor Yang Berhubungan Dengan Kesiapan 
Persalinan Di Puskesmas Banguntapan II Bantul Yogyakarta. Doctoral Dissertation, Universitas Aisyiyah Yogyakarta.

Sari, E. And Sudarmiati, S. (2017). Pengaruh Pendidikan Kesehatan Terhadap Tingkat Pengetahuan Ibu Hamil Tentang Tanda Bahaya Kehamilan Di Puskesmas Karangdoro. Doctoral Dissertation, Diponegoro University.

Syafiudin, M., Wantiyah, W. And Kushariyadi, K. (2018). Pengaruh Pendidikan Kesehatan Metode Brainstorming Dan Video Terhadap Pengetahuan Tentang Demam Berdarah Pada Keluarga Di Wilayah Kerja Puskesmas Puger Kabupaten Jember. PustakaKesehatan, 6(1),141 -146 .
Umairoh, U., Suwarni, L. And Mardjan, M. (2019). Pengaruh Penggunaan Model Pembelajaran Snowball Throwing Terhadap Tingkat Pengetahuan Dan Sikap Siswa Tentang Pendewasaan Usia Perkawinan Di Mts An-Nur Desa Sungai Asam. Jurnal Kesmas (Kesehatan Masyarakat) Khatulistiwa, 6(4), 135-145. Doi: 10.29406/Jkmk.V6i4.1980.

Winancy, W., Raksanagara, A.S. And Fuadah, Y. (2015). Perbandingan Penerapan Metode Brainstorming Dan Buzz Group Terhadap Peningkatan Pengetahuan Suami Ibu Hamil Tentang Tanda Bahaya Kehamilan, Persalinan, Dan Nifas (Studi Kasus Di Bogor). Seajom: The Southeast Asia Journal Of Midwifery, 1(1), 1-9. 